\title{
CONCEIÇÃO EVARISTO: DA MULHER NEGRA À ESCRITORA
}

\author{
Elen Karla Sousa da Silva \\ Sebastião Marques Cardoso ${ }^{2}$
}

Da língua cortada, digo tudo, amasso o silêncio e no farfalhar do meio som solto o grito do grito do grito e encontro a fala anterior, aquela que emudecida, conservou a voz e os sentidos nos labirintos da lembrança. ${ }^{3}$

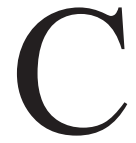

onceição Evaristo cresceu ouvindo sua família contar estórias dos avós e bisavós. Durante a juventude, lia bastante. Precisou ler muito, pois para ela a literatura era uma maneira de buscar explicação para muitas coisas, era uma infância sem televisão ou rádio, restava-lhe somente a leitura. O primeiro contato da autora com a literatura ocorreu por meio das palavras, das estórias contadas em sua casa. So-

1 Doutoranda em Letras pela Universidade Federal do Rio Grande do Sul (UFRGS).elenuema@ gmail.com.

2 Doutor em Teoria e História Literária pela Universidade Estadual de Campinas (Unicamp). sebastiaomarques@uol.com.br.

3 Conceição Evaristo, Poemas da recordação e outros movimentos, Belo Horizonte: Nandyala, 2008. 
mente depois teve acesso ao livro impresso, através de uma tia que havia se tornado servente da biblioteca pública em Belo Horizonte, que propiciou a Evaristo esse contato. ${ }^{4}$

Em entrevista, indagada se iniciaria abordando sua infância, Evaristo diz: "Sim, minha infância, apesar de tudo, é um período que gosto de relembrar. Digo apesar porque é uma etapa de minha vida fortemente marcada pela pobreza, pela carência material". ${ }^{5}$ É notório que nessa fase da vida ela passou por problemas financeiros, não obstante vivia envolvida pela fortuna das narrações contadas em família, atualmente transfiguradas em memórias poéticas, segundo Evaristo apresenta em seu artigo "Gênero e etnia: uma escre(vivência) de dupla face":

Do tempo/espaço aprendi desde criança a colher palavras. A nossa casa vazia de móveis, de coisas e de muitas vezes de alimento e de agasalhos, era habitada por palavras. Mamãe contava, minha tia contava, meu tio velhinho contava, os vizinhos amigos contavam. Eu, menina, repetia, intentava. Cresci possuída pela oralidade, pela palavra. As bonecas de pano e de capim que minha mãe criava para as filhas que nasciam com nome e história. Tudo era narrado, tudo era motivo de prosa-poesia. ${ }^{6}$

Evaristo acredita que a gênese de sua escrita deriva do amontoado de histórias que ouviu quando criança. ${ }^{7}$ Palavras, lembranças de sua infância, histórias que faziam parte de seu lar e imediações, que traduzem sua escrita ficcional.

Como modelos de influência na sua disposição para escrever, a autora descreve alguns fatos vivenciados com a mãe, que, apesar de não

4 Eduardo de Assis Duarte, "Literatura e afro-descendência", in Niyi Afolabi, Marcio Barbosa e Esmeralda Ribeiro (org), The Afro-Brazilian Mind: contemporary Afro-Brazilian Literary and Cultural Criticism (Toronto: África World Press, 2006).

5 Eduardo de Assis Duarte e Maria Nazareth Soares Fonseca (orgs), Literatura e afrodescendencia no Brasil: antologia crítica, Belo Horizonte: Editora UFMG, 2011. v. 2, p. 103.

6 Conceição Evaristo, "Gênero e etnia: uma escre(vivência) de dupla face", in Nadilza M. de Barros Moreira e Liane Schneider, Mulheres no mundo: etnia, marginalidade, diáspora (João Pessoa: Ideia, Editora UFPB, 2009).

7 Conceição Evaristo, "Da grafia-desenho de minha mãe, um dos lugares de nascimento de minha escrita", in Marcos Antonio Alexandre (org), Representações performáticas brasileiras: teorias, práticas e suas interfaces (Belo Horizonte: Mazza, 2007), pp. 16-21. 
possuir instrução escolar, transferiu a importância dos registros textuais na imaginação da filha através da oralidade. Um dos exemplos trata do que fazia sua mãe ao desenhar um sol no chão, em uma condição de anseio de influenciar o clima, fazendo com que o sol nascesse no céu, visto que o trabalho de lavar roupas dependia disso; outro é a anotação das roupas entregues, caracterizada como um acordo entre patroa e lavadeira. Essas experiências deixaram em Evaristo, prematuramente, a certeza sobre o valor do registro escrito. $\mathrm{O}$ último exemplo faz referência ao diário escrito pela mãe, como notas avulsas de fatos da vida que corria, marcando a possibilidade de integrar a vivência e o lírico também na escrita. Através desses escritos, a menina e, depois, a adolescente, já experimentando textos mais organizados, entende o ato de escrever como uma ação de invenção e engenho transformador. Conceição Evaristo explica:

retomando a imagem da escrita diferencial de minha mãe, que surge marcada por um comprometimento de traços e corpo (o dela e nossos), e ainda a um de diário escrito por ela, volto ao gesto em que ela escrevia o sol na terra e imponho a mim mesma uma pergunta. $\mathrm{O}$ que levaria determinadas mulheres, nascidas e criadas em ambientes não letrados e, quando muito, semialfabetizados, a romperem com a passividade da leitura e buscarem o movimento da escrita? Tento responder. Talvez, estas mulheres (como eu) tenham percebido que se o ato de ler oferece a apreensão do mundo, o de escrever ultrapassa os limites de uma percepção da vida. Escrever pressupõe um dinamismo próprio do sujeito da escrita, proporcionando-lhe a sua autoinscrição no interior do mundo. E, em se tratando de um ato empreendido por mulheres negras, que historicamente transitam por espaços culturais diferenciados dos lugares ocupados pela cultura das elites, escrever adquire um sentido de insubordinação. ${ }^{8}$

Essas mulheres mencionadas por Evaristo, entre as quais ela se insere, teriam lhe motivado o gosto de escrever, uma vez que se empenhavam para se inscrever num outro espaço, distinto do que lhes era 
imposto por inúmeras articulações dominadoras. É relevante entender o quanto esse ato em benefício de sentimentos positivos estabelece relação com o ato da escrita, desde o início assinalado pelo anseio de se sustentar com voz própria, diferente do contexto de subalternidade que a vida aparentava querer-lhe impor.

Evaristo, em sua escrita, faz uso de diversos temas por meio das metáforas que aparecem em inúmeras formas no seu texto literário: uma delas se trata da diáspora negra, entendida aqui como a representação da migração frequente que se sucede individual e coletivamente com suas personagens, abrangendo grupos negros.

Ressaltamos que o vocábulo diáspora pode adquirir um sentido de “dispersão", conforme sua abrangência de significações, no qual pode exprimir "desatenção", "fuga". ${ }^{9}$ A protagonista submerge em condições de dispersão, isto é, deserta para inúmeros locais de um passado longínquo na pretensão de reconstituir sua história dividida por vivências envoltas em amarguras: "às vezes, era um recordar feito de tão dolorosas, de tão amargas lembranças que lágrimas corriam sobre o seu rosto"; ${ }^{10}$ de outro modo, "outras vezes eram tão doces, tão amenas as recordações que, de seus lábios surgiam sorrisos e risos". ${ }^{11}$

Ademais, a referida autora, através do poema "Vozes-Mulheres", ${ }^{12}$ expressa as marcas de um passado de angústia: “A voz de minha bisavó/ ecoou criança/ nos porões do navio". Nas imagens evocadas assomam-se a diáspora e a atrocidade do deslocamento nos navios do tráfico, ao entrelaçar de modo cru duas imagens que estampam o caráter da ação escravocrata: a criança e os porões.

Essa temática, que se apresenta nos poemas e narrativas, se relaciona a certa aflição, ansiedade proveniente de uma procura ininterrupta por um espaço onde o negro se sinta valorizado e viva com dignidade. Outra tônica trata da irmandade feminina na produção de Evaristo, representação de solidariedade mais oportuna se analisarmos suas

9 "Diáspora", in Dicionário Houaiss Eletrônico (São Paulo: UOL, 2019), <https://bit.ly/ 2VwMYwo>, acessado em 14/10/2019.

10 Conceição Evaristo, Ponciá Vicêncio, Belo Horizonte: Mazza, 2003, p. 93.

11 Evaristo, Ponciá Vicêncio, 2003, pp. 93-94.

12 Evaristo, Poemas da recordação, pp. 10-11. 
personagens femininas. Na produção da escritora, sobretudo a que foi divulgada no decorrer das edições dos Cadernos Negros, ${ }^{13}$ ao lado de suas personagens protagonistas femininas, suas filhas e mães, aparecem personagens masculinos; contudo, eles não são alcunhados, apelidados, nomeados, apresentando ação sempre secundária, distintamente do que ocorre com as personagens femininas, que possuem sempre nome próprio, uma identificação. Essa preferência da autora sugere o propósito de enaltecer ações das mulheres, na maneira como são resolvidas e decididas questões familiares e em grupos afrodescendentes. A escritora cria em seus textos circunstâncias nas quais essa contribuição entre mulheres negras de diversas gerações recupera nelas a autoestima e estimula o vínculo ancestral.

Na ficção de Evaristo, esse apoio, reciprocidade e "irmandade" são intrínsecos às afrodescendentes, constituindo um tipo de união que delineia a transferência da memória da tradição da cultura afro-brasileira e a prática de solidariedade em ocasiões complexas, em específico as que abarcam conflitos de raça e gênero; na maioria das vezes, e com frequência, há conflitos ligados a questões de classe.

Conforme a autora, sua produção é influenciada pelos fatos que viu, viveu, ouviu. Afirmou, em inúmeras entrevistas, que não possui a intenção de escrever e publicar sua autobiografia, justifica que não conseguiria contar a sua história de modo fiel, sem fabulizar nada, e afirma que seus escritos são "memórias ficcionalizadas". Ratificamos isso com o texto introdutório de uma de suas obras:

Invento? Sim, invento, sem o menor pudor. Então, as histórias não são inventadas? Mesmo as reais, quando são contadas. Desafio alguém a relatar fielmente algo que aconteceu. Entre o acontecimento e a narração do fato, alguma coisa se perde e por isso se acrescenta. O real vivido fica comprometido. E, quando se escreve, o comprometimento (ou o não comprometimento) entre o vivido e o escrito aprofunda mais o fosso. Entretanto, afirmo 
que, ao registrar estas histórias, continuo no premeditado ato de traçar uma escrevivência. ${ }^{14}$

Acreditamos que essa escrevivência define a gênese da escrita da autora, ocupando a posição de autobiografia, segundo Constância Lima Duarte, ela "pode ser vista como provocação para o eu lírico transcender o biográfico". ${ }^{15}$ Segundo Evaristo, essa expressão caracteriza melhor sua escrita, que espelha o que a autora é, seus pensamentos, e proporcionalhe abordar a si mesma sem fazer nomeações, as personagens são criadas com base em algumas lembranças de sua infância e em histórias lidas, momentos vividos, canções ouvidas. O processo criativo se constitui alicerçado nessas experiências:

creio que a gênese de minha escrita está no acúmulo de tudo que ouvi desde a infância. $\mathrm{O}$ acúmulo de palavras, das histórias que habitavam nossa casa e adjacências. Dos fatos contados a meia voz, dos relatos da noite, segredos, histórias que as crianças não podiam ouvir. Eu fechava os olhos fingindo dormir e acordava todos os meus sentidos. O meu corpo por inteiro recebia palavras, sons, murmúrios, vozes entrecortadas de gozo ou dor, dependendo do enredo das histórias. De olhos cerrados, eu construía as faces de minhas personagens reais e falantes. Era um jogo de escrever no escuro. No corpo da noite. Na origem da minha escrita, ouço gritos, os chamados das vizinhas debruçadas sobre as janelas, ou nos vãos das portas contando em voz alta uma para as outras as suas mazelas, assim como as suas alegrias. Como ouvi conversa de mulheres! Falar e ouvir, entre nós, era, talvez, nossa única defesa, o único remédio que possuíamos. ${ }^{16}$

14 Conceição Evaristo, "Insubmissas lágrimas de mulher", in Eduardo de Assis Duarte e Maria Nazareth Soares Fonseca (orgs), Literatura e afrodescendência no Brasil: antologia crítica (Belo Horizonte, UFMG, 2011), v. 2, p. 9.

15 Constância Lima Duarte, "Gênero e violência na literatura afro-brasileira", in Marcos Antônio Alexandre, Constância Lima e Eduardo de Assis Duarte (orgs.), Falas do outro: literatura, gênero, etnicidade (Belo Horizonte: Nandyala, NEIA, 2010), p. 231.

16 Evaristo, "Da grafia-desenho", p. 19. 
A escrevivência é o espírito de uma coletividade. A autora é porta-voz dos impossibilitados de falar e apesar de sua escrita ser um ato coletivo, ao mesmo tempo é pessoal, pois quem escreve, escreve pelos seus, mas sobretudo por si próprio. Evaristo expressa que sua produção é a manifestação de suas angústias e como diz possuir apenas desenvoltura com a literatura, justifica: "Escrevo porque não sei dançar nem cantar. Não tenho outras formas de manifestar minhas angústias [...]. Se não escrever, adoeço", afirmou em uma conferência na Universidade Federal de Minas Gerais (UFMG), em 2012.

Evaristo parte de personagens concretos que, segundo ela, são a "escrita de um corpo, de uma condição, de uma experiência negra no Brasil". ${ }^{17}$ Ao construir, em uma narrativa, uma doméstica, por exemplo, a autora se autoconstrói, constrói sua mãe, sua irmã, pessoas que fazem parte do seu convívio. Desse modo, ela atribui ao seu texto o estatuto da escrevivência, o compromisso entranhado de compreensão da literatura pelos gestos da vida. O conceito foi desenvolvido numa entrevista dada ao programa on-line Imagem da Palavra (2012). Ela assegura: "eu acho que pra você escrever, o que opera essa matéria é o mundo, é a vida. Por isso, é a escrevivência, se eu me retirar para escrever, pode saber que eu já colhi tudo lá fora". Portanto, a escrita, em prosa ou em verso, encontra-se entrelaçada à sua própria vivência, ao aproximar os caminhos entre a ficção e a realidade, a partir do acúmulo de memórias e experiências vivenciadas desde sua infância. E, de acordo com Evaristo, "É necessário comprometer a vida com a escrita ou é o inverso? Comprometer a escrita com a vida?". ${ }^{18}$

A participação de Evaristo em congressos e seminários literários tem sido uma das mais atuantes, sendo marcada por suas reflexões e análises a respeito da produção de escritoras afro-brasileiras, e sobre a função (ou o papel) da mulher negra na sociedade. Como resultado dessas reflexões, a autora tem produzido inúmeros ensaios, dentre os quais: "Gênero e etnia: uma escrevivência de dupla face" (2005); "Dos risos, dos silêncios e das falas" (2006); e "Conversas de lavadeiras" (2006).

17 Evaristo, "Da grafia-desenho", p. 20.

18 Evaristo, "Da grafia-desenho", p. 17. 
Em um desses textos, a escritora fala de sua escrita e se posiciona politicamente como mulher e como negra na sociedade brasileira:

Gosto de escrever, na maioria das vezes dói, mas depois do texto escrito, é possível apaziguar um pouco a dor, eu digo um pouco [...]. Escrever pode ser uma espécie de vingança, às vezes fico pensando um pouco sobre isso. Não sei se vingança, talvez desafio, um modo de ferir um silêncio imposto, ou ainda, executar um gesto de teimosa esperança. Gosto de dizer, ainda, que a escrita é para mim o movimento de dança-canto que o meu corpo executa, é a senha pela qual eu acesso o mundo. ${ }^{19}$

Evaristo se reconhece inserida na "Literatura afro-brasileira", que para o professor Duarte, fundador do site Literafro é "um conceito em construção", ${ }^{20}$ e enfatiza sua vivência e produção literária, que brotam das rasuras do discurso literário brasileiro embranquecido, e imbuído no imaginário de uma suposta democracia racial. ${ }^{21}$

E, nesse sentido, afirmo que, quando escrevo, sou eu, Conceição Evaristo, eu sujeito a criar um texto e que não me desvencilho de minha condição de cidadã brasileira, negra, mulher, viúva, professora, oriunda das classes populares, mãe de uma especial menina, Ainá, etc., condições essas que influenciam na criação de personagens, enredos ou opções de linguagem a partir de uma história, de uma experiência pessoal que é intransferível. ${ }^{22}$

19 Conceição Evaristo, "Da representação à auto-representação da mulher negra na literatura brasileira", Palmares, ano 1, n. 1 (2005), pp. 57-62.

20 Site de Literatura afro-brasileira, com textos e biografias de autores(as), além de artigos críticos sobre eles(as): <www.letras.ufmg.br/literafro>.

21 Não existe democracia racial efetiva onde o intercâmbio entre indivíduos pertencentes a "raças" distintas começa e termina no plano da tolerância convencionalizada. Esta pode satisfazer às exigências do bom-tom, de um discutível "espírito cristão" e da necessidade prática de "manter cada um no seu lugar". Contudo, ela não aproxima realmente os homens senão na base da mera coexistência no mesmo espaço social e, onde isso chega a acontecer, da convivência restritiva, regulada por um código que consagra a desigualdade, disfarçando-a e justificando-a acima dos princípios de integração da ordem social democrática. Florestan Fernandes. "Prefácio", in F. H. Cardoso e Octávio Ianni, Cor e mobilidade social em Florianópolis (São Paulo: Companhia Editora Nacional, 1960), p. XIV

22 Conceição Evaristo, "Depoimento", in Eduardo de Assis Duarte e Maria Nazareth Soares Fonseca, Literatura e afrodescendência no Brasil: antologia crítica (Belo Horizonte: Editora 
Enquanto as mulheres negras eram usadas para contar narrativas para adormecer os filhos dos senhores, a literatura produzida por negros não tem essa função, não se quer mais que a casa-grande continue adormecida, mas, na verdade, espantar o "sono" da casa-grande. Nesse sentido, para Evaristo, a "escrevivência não pode ser lida como histórias para "ninar os da casa grande' e sim para incomodá-los em seus sonos injustos". ${ }^{23}$

Assim, podemos reiterar que Ponciá Vicêncio (2003) narra a experiência de Ponciá, que deixa sua família em terras de antigos senhores de escravos em busca de uma vida melhor e, posteriormente, encara uma cruel realidade, bem distinta dos sonhos que possuía. É um romance que descreve a identidade afro-brasileira, não como objeto de estudo ou personagem estereotipada, mas a partir da voz de uma escritora situada num contexto sociocultural e político, que interage com seu espaço repleto de profundidade.

Evaristo expõe a valorização e a busca de uma ancestralidade africana, inclinada à construção de uma nova representação do atual negro, que contrasta com os estereótipos e objetiva comprovar os enigmas, resistências sofridas e lutas, como assinalam Duarte e Campos. ${ }^{24}$

As vivências são transformadas em "escrevivências", isto é, "a escrita de um corpo, de uma condição, de uma experiência negra no Brasil". ${ }^{25}$ Desse modo, a temática do preconceito racial e das denúncias sociais presentes em suas produções advém de sua condição de mulher negra.

A herança que se alarga de uma geração a outra é muito significativa na história de uma família e não seria possível ser diferente no romance. A escritora explora cuidadosamente a infelicidade da personagem por meio das perdas, falecimento dos sete filhos, do pai e do avô, separação do irmão e da mãe. Esse sofrimento cerca Ponciá, que faz uso das reminiscências como modo de obtenção do autoconhecimento através da interação entre o passado e o presente.

UFMG, 2011), v. 4, p. 115.

23 Evaristo, "Da grafia-desenho", p. 21.

24 Maria Consuelo Cunha Campos, "Conceição Evaristo", in Eduardo de Assis Duarte e Maria Nazareth Soares Fonseca (orgs), Literatura e afrodescendência no Brasil: antologia crítica, Belo Horizonte: Editora UFMG, 2011. v. 2, pp. 207-226.

25 Evaristo, "Da grafia-desenho", pp. 16-21. 
O enredo liga o lírico ao social e sua produção intensamente questionadora se desvia de um lirismo intimista, vigorando o que pertence ao social e humano. Em vista disso, temos um narrador em terceira pessoa, observador; entretanto preocupado com os interesses das personagens, ressaltando deles o que é individual, ilustrando o sucessivo conflito entre o individual e o coletivo, fazendo uso de uma linguagem concisa, com densos episódios. Em síntese, a obra em estudo retrata a busca da personagem pela identidade, expressando o anseio de se definir em um contexto marcado pelas desigualdades sociais, econômicas e raciais.

Diante do exposto, entendemos que a literatura produzida por Evaristo traz a condição do negro brasileiro, notadamente a da mulher negra brasileira, e frisamos que a literatura afro-brasileira expõe a condição, como povos herdeiros que passaram por um processo de escravização, dos africanos no processo de colonização, escravizados no próprio solo.

\section{Ponciá Vicêncio: uma narrativa diaspórica}

Diáspora ${ }^{26}$ negra refere-se ao percurso dos negros africanos pelo Atlântico em direção às Américas. Paul Gilroy, em O Atlântico negro (2012), apresenta o quadro de um navio negreiro, no qual cadáveres mortos são espalhados no mar durante a aproximação de uma intempérie: "Deve-se enfatizar que os navios eram os meios vivos pelos quais se uniam os pontos naquele mundo atlântico. Eles eram elementos móveis que representavam os espaços de mudança entre os lugares fixos que eles conectavam". ${ }^{27}$ A importância do que afirma Gilroy está não apenas no destaque da barbaridade do processo escravocrata, mas também no enredamento dos princípios que abrangem o sistema diaspórico. Devemos pensar no Atlântico como um sistema de câmbio cultural e político e não exclusivamente o lugar de agrupamentos abstratos mercantis.

26 Os negros de origem africana deportados para outros continentes e seus descendentes (Kabengele Munanga, Negritude: usos e sentidos, 3. ed., Belo Horizonte: Autêncica, 2012, p. 85). Para Walter, a palavra "diáspora" vem do verbo grego speiro e significa "semear" e "disseminar". A diáspora designou raízes, terra (ponto de origem atual ou imaginado) e parentesco (comunidade local e grupo globalmente dispersado): a perda do país natal e o desejo de volta. Roland Walter, Afro-América: diálogos literários na diáspora nas Américas, Recife: Bagaço, 2011, pp. 42-43.

27 Paul Gilroy, O Atlântico Negro: modernidade e dupla consciência. São Paulo: Editora 34, 2012. 
A palavra diáspora sugere uma trama de relações, imaginadas ou fictícias, entre povos dispersos, cuja noção de grupo é sustentada por distintos contatos e formas de comunicação, como cultura, família, viagem, entre outros. Salientamos também que a conceituação é considerada originária da história de dispersão do povo judeu e, por conseguinte, de sua errância pelo mundo. Em uma visão moderna, no entanto, o termo foi importado para a história dos negros capturados, escravizados e, assim, também disseminados por outros continentes no decorrer do período colonial, momento de constituição do sistema capitalista, que fez amplo uso do trabalho escravo para acumulação de capital. Esse processo originou o que denominamos diáspora negra ou diáspora africana.

Nas últimas décadas, a expressão tem sido utilizada por pesquisadores que estudam africanos e seus descendentes que habitam em comunidades fora da África, em decorrência da comercialização desses povos em diferentes continentes. Diáspora negra, desse modo, relaciona-se a questões como escravidão, preconceito, genocídio e a consecutiva marginalização desses grupos em vários níveis. Efetivamente, o tema também é discussão rotineira na literatura afro-brasileira e aparece em inúmeros textos de Evaristo.

Stuart Hall julga que, "na situação da diáspora, as identidades se tornam múltiplas", não sendo, desse modo, fixas, pois em um âmbito diaspórico transportam a dispersão, a propagação que finda multiplicando-as. ${ }^{28}$ Assim, apesar de ser notório que Ponciá Vicêncio não tinha estado num navio negreiro, ela possuía a percepção do abalo que a escravização causou em sua família: a mudez, a falta de diálogo sobre as marcas deixadas em seus ancestrais e difundidas às gerações seguintes.

Além disso, a viagem efetivada no Brasil depois da abolição da escravatura representava a migração para a cidade. No entanto, essa audácia, esse espírito, aventureiro não qualificava a todos. Ponciá Vicêncio, contudo, simboliza, apesar do receio e das inquietudes, alguns dos que resolveram colocar-se no cruzamento do ambiente rural com o urbano. 
Não podia ficar ensaiando despedidas. O trem partiria no outro dia cedo. Se perdesse aquele, só daí a alguns tantos dias, quase um mês. Deixava um abraço para o irmão, não poderia ir às terras dos brancos procurar por ele. A mãe de Ponciá olhou meio incrédula para a moça, ao ouvir a filha falar da decisão de partir. Por que uma ida tão repentina, como um gesto de quase fuga? Ponciá não conseguiu explicar que sua urgência nascia do medo de não conseguir partir. Do medo de recuar, do desespero por não querer ficar ali repetindo a história dos seus. Agora na cidade, sozinha, para onde deveria ir? O que deveria fazer? ${ }^{29}$

Ponciá procura libertar-se do seu lugar de origem (território rural), espaço com o qual possuía uma relação de pertencimento constituída pelos vínculos com os seus antepassados. Contudo, esses laços com o território e com os seus são fraturados e, ao migrar para a cidade, o único elemento ancestral que a acompanha é a dor.

Paul Gilroy discute largamente a temática do trânsito, do processo de migração da diáspora, numa alusão ao lugar onde se principiou uma interação entre as culturas negras e demais. ${ }^{30}$ Esses câmbios, conforme Gilroy, não podem ser entendidos nem refletidos, apresentam uma única significação, isto é, as recíprocas influências se adicionam à diáspora, estabelecendo novas e intricadas realidades culturais. Além disso, considerando o trânsito da diáspora, Florentina Souza entende que semelhante experiência

rechaça etnocentrismos, possibilitando uma análise mais abrangente, não só das adequações que as várias etnias transplantadas realizaram com o fim de sobreviverem em terra estrangeira, mas de negociações de ordens diversas, voluntárias ou não, estabelecidas nas conexões com as culturas ocidentais da colônia portuguesa na América. ${ }^{31}$

29 Evaristo, Ponciá Vicêncio, pp. 37-38.

30 Gilroy, O Atlântico Negro.

31 Florentina da Silva Souza, Afro-descendência em Cadernos Negros e Jornal do MNU, Belo Horizonte: Autêntica, 2005, p. 160. 
Assim, é relevante a discussão sobre a temática da diáspora negra para os escritores afro-brasileiros, pois a ligação que se constituiu entre a cultura dos seus ancestrais e do país para onde foram trazidos, mediada pelos contextos sociais resultantes do período da escravidão, carece de retificação e reflexão a respeito da extensão e enredamento desse processo e suas implicações. Em vista disso, esse assunto é constante inspiração tanto entre as autoras que trabalham com uma configuração histórica referente ao período de escravidão, como Ana Maria Gonçalves na narrativa Um defeito de cor (2007), quanto para escritoras como Conceição Evaristo, que escolhem abordar efeitos psicológicos e sociais da pós-escravidão, os quais se alargam até a atualidade, sendo ainda vivenciados pelos afro-brasileiros. Evaristo simula a temática da diáspora pelas viagens, simbólicas e reais, de personagens afrodescendentes à procura de uma identidade-lugar. A discussão se amplia por meio da migração constante dessas personagens, acrescida de uma aflição permanente sobre a história dos seus antepassados, sobre quem é, em síntese, uma procura por si mesmo, sua história, cultura, lugar e sentido.

Ao considerar elementos da literatura afrodescendente, Roland Walter entende a aflição, concebida pela temática da viagem diaspórica, como um dos vestígios dessa narrativa ficcional. ${ }^{32} \mathrm{O}$ autor intitula essa inquietude de "errância esquizofrênica", expressão que utiliza para explicar o descontentamento, a aflição que segue as personagens afrodescendentes e as faz se moverem frequentemente, e afirma que "a errância continua, não se pode sair dela porque o passado não foi, mas continua sendo; ou seja, na experiência da diáspora negra, o tempo em vez de passar, se acumula para sedimentar em memória coletiva". ${ }^{33}$ No enredo em estudo, esse assunto é representado de várias formas. A personagem comumente é conduzida a uma busca/fuga que a encaminha à migração, porém salientamos que essa migração não é somente física, geográfica, mas também emocional.

As representações exercem uma função importante na configuração do estilo de escrita de Evaristo, revestindo-se de maior significação simbólica por meio da construção metafórica, que acentua um sentimento ou uma mensagem, como no caso da proposta de "labirinto", lugar

32 Walter. Afro-América.

33 Walter, Afro-América, p. 168. 
favorável ao sentimento de perturbação/desorientação, figurado pelas estradas e ruas desconhecidas. Situar as personagens nessas condições é o que confirma a representação de uma busca diaspórica.

A pesquisadora Flávia Santos Araújo, ao tratar sobre a questão identitária em Ponciá Vicêncio (2003), ressalta o conteúdo da memória coletiva, a relevância da recordação e do elo da protagonista com o passado coletivo dos negros diaspóricos e com a "memória cultural dos africanos escravizados". ${ }^{34}$ Apesar de memória coletiva e perspectiva historiográfica não serem motes basilares deste artigo, compreender a diáspora africana e as relações das vivências e percursos da protagonista em estudo sugere uma consideração do passado coletivo escravagista a que seus ascendentes foram sujeitados e, nessa perspectiva, possui pertinente paridade com um ponto da pesquisa de Araújo.

A partir do artigo "A errância diaspórica como paródia da procura em Ponciá Vicêncio", de Conceição Evaristo, e "Um defeito de cor", de Ana Maria Gonçalves"; 35 a pesquisadora Aline Alves Arruda avalia que a migração "interna" de Ponciá é uma metáfora diaspórica. ${ }^{36}$ Em outro estudo, intitulado "Ponciá Vicêncio, de Conceição Evaristo: um Bildungsroman feminino e negro", Arruda assinala uma analogia da viagem de Ponciá com as migrações transnacionais. ${ }^{37}$ Notamos que as nuanças entre o ambiente rural e a cidade, que favorecem tal observação, são tão intensas que proporcionam, efetivamente, uma simetria às atuais diásporas transnacionais a que se submeteram a nação negra de ascendência africana.

Para Édouard Glissant, o passado dos povos africanos, que passaram pelo processo da diáspora, não pode ser recuperado de maneira objetiva e absoluta diante das sistemáticas interdições, imposições cultu-

34 Flávia Santos Araújo, "Uma escrita em dupla face: a mulher negra em Ponciá Vicêncio, de Conceição Evaristo" (Dissertação de Mestrado, Universidade Federal da Paraíba, 2007).

35 Ana Maria Gonçalves, Um defeito de cor, Rio de Janeiro: Record, 2007.

36 Aline Alves Arruda Alves, "Ponciá Vicêncio, de Conceição Evaristo: um Bildungsroman feminino e negro" (Dissertação de Mestrado, Universidade Federal de Minas Gerais, 2007).

37 Podemos definir as migrações transnacionais como o processo pelo qual o imigrante constrói elemento de ligação com seu país embrionário e no país de destino, isto é, entre distintas diásporas. 
rais ocidentais e do horror do holocausto sofrido. ${ }^{38}$ A memória dos negros, entendida por Glissant como vestígio, pode, entretanto, ser recuperada ou imaginada subjetivamente, através da in(ter)venção poética, nas diversas áreas da cultura. Nesse sentido, o autor evidencia o papel criativo no esforço de preencher os vazios a partir dos vestígios, que ficaram inacessíveis: "deve também ser sonhado de forma profética, para as pessoas, comunidades e culturas cujo passado, justamente, foi ocultado". ${ }^{39} \mathrm{Ou}$ seja, a ficção pode contribuir para pensar rotas culturais possíveis, mas subjetivamente ligadas à experiência da diáspora. Isso posto, entendemos que há uma ponte necessária entre o trabalho de Conceição Evaristo e o passado de que ela se apropria, ao recriá-lo. Evaristo acredita que, ainda que incompleta, a reminiscência da cultura, memória e ancestralidade dos povos diaspóricos na literatura pode atuar como paradigma para o sujeito atual. Por isso, a necessidade da valorização da memória, da identidade e da ancestralidade na ficção. Enfim, essa preocupação de Evaristo está em consonância com o recente fenômeno, entre os negros brasileiros, de buscar uma integração entre as mais variadas formas e expressões de resgate da identidade étnica.

O percurso trilhado por Ponciá, quer no imaginário, quer no plano físico da ficção, delineia e denuncia eventos históricos vividos pelos afrodescendentes em uma condição particular e coletiva que, durante séculos, foram maquiadas e/ou disfarçadas pela história, inseridas ou não em instituições educacionais. Essas passagens ratificam, consecutivamente, o não lugar do negro na sociedade, entendido pela perturbação ao abandonar o campo e se retirar à procura de uma vida melhor. Porém, a protagonista não terminaria sua busca na cidade (zona urbana), pois depressa compreendeu que não havia espaço para ela ali também, tudo era difícil, inclusive encontrar um apoio para encostar a cabeça à noite, até mesmo uma fatia de pão para se alimentar.

Ponciá era uma mulher simples, humilde, do campo, que não conhecia a pressa da vida urbana, mas, ainda assim, entendia o universo em que estava envolvida, pois "enxergava de olhos abertos e fechados. Desde

38 Édouard Glissant, Introdução a uma poética da diversidade, Tradução de Enilce do Carmo Albergaria Rocha, Juiz de Fora: Editora UFJF, 2005.

39 Glissant, Introdução a uma Poética, pp. 102-103. 
pequena, assistia às coisas que muita gente não percebia". ${ }^{40}$ Superando as dificuldades iniciais de sua chegada à cidade grande, ela conseguiu um trabalho de empregada doméstica, profissão por vezes designada às mulheres negras. De tal modo, é que "ela mesma havia chegado à cidade com o coração crente em sucessos e eis no que deu. Um barraco no morro. Um ir e vir para a casa das patroas. Umas sobras de roupas e de alimento para compensar um salário que não bastava" ${ }^{41}$

E continua: "Estava de coração leve, achava que a vida tinha uma saída. Trabalharia, juntaria dinheiro, compraria uma casinha e voltaria para buscar seus entes queridos, mãe e irmão. A vida lhe parecia possível e fácil". ${ }^{42}$ Entretanto, a fuga que a existência lhe apontava era diferente da que sonhara e prontamente percebeu que a viabilidade de uma vida melhor se resumia a fantasias. Uma vida sem direção, que a fazia se esquivar da realidade dura, amparando-se em si mesma, em sua ausência interior. Ponciá, em sua languidez: "perguntava-se se valera a pena ter deixado a sua terra". ${ }^{43}$

Ressaltamos que Ponciá representa os povos diaspóricos, pois, na obra, são vários os componentes adicionados para construir a conjuntura cultural da diáspora: noções sobre os costumes, as religiões africanas, a imagem do avô, a arte no barro; por fim, uma pluralidade de alusões culturais que explanam a real vivência dos afrodescendentes, os medos e os deleites, metaforizados nos termos "sangue e garapa".

Ao sair da Vila Vicêncio e chegar à cidade, a personagem estabelece relação com um meio social que segrega o "Outro", devido a este não integrar a classe social dominante, através das histórias dos que apostaram na sorte e não obtiveram êxito. E como afirma Fernandes, "segregação do 'negro' é sutil e dissimulada". ${ }^{44}$ São numerosos os informes que descrevem as desgraças dos homens que buscaram uma condição melhor de vida e se perderam pela cidade.

40 Evaristo, Ponciá Vicêncio, p. 41.

41 Evaristo, Ponciá Vicêncio, p. 82.

42 Evaristo, Ponciá Vicêncio, p. 42.

43 Evaristo, Ponciá Vicêncio, p. 33.

44 Florestan Fernandes, O negro no mundo dos brancos, São Paulo: Difel, 1972, p. 43. 
Algumas vezes, ela já havia passado a noite em claro, em festa ou velório, mas nunca sozinha. Sentia frio e medo. [...] Ponciá descobriu alguns já deitados, agasalhados em jornais e sentiu um calafrio. Lembrou-se dos santos que estavam lá dentro, das velas e dos castiçais, dos vitrais coloridos, dos bancos largos e lustrosos de madeira. [...] Olhou novamente para os lados, todos calmos, muitos até dormindo. Ela abriu a trouxa, tirou o terço de lágrimas de Nossa Senhora, beijando respeitosamente as contas escuras que diluíam na cor mesma da noite, benzeu-se e começou a rezar a Ave-Maria. ${ }^{45}$

Ponciá, ao chegar à cidade, deslocada do seu ambiente de origem, depois de adormecer na porta da igreja, ao lado dos "mendigos, crianças, mulheres e homens", e de com eles compartilhar a fome, a pobreza e a negligência social diante daquela ocasião, em oposição ao "chão liso, brilhante, quase escorregadio da igreja" ${ }^{46}$ pede auxílio a uma mulher, em quem confia, por ela lembrar a figura de sua mãe:

Escolheu uma mulher de certa idade, que se parecia com sua mãe, para poder exercitar o treino de abordagem para pedir trabalho. A pedinte olhou para Ponciá e sorriu, dizendo que não tinha trabalho nenhum para oferecer a moça, mas, se quisesse, poderiam pedir esmolas juntas. ${ }^{47}$

Distante da família, a personagem perde a ligação que a vincula a sua identidade e, ao não encontrar esses contatos de reiteração do "eu", deixa de pertencer ao grupo, tornando-se "outro", um sujeito de fora, sentenciado a viver à margem, distante dos olhares da classe dominante estipuladora de regras. Isso é apresentado no fragmento que descreve a ida de Ponciá para a cidade, quando ela se observa envolvida por vários outros excluídos e à margem da sociedade.

Destacamos que o modo de vida simples, a culinária, os hábitos, as tradições, os costumes e a herança cultural africana, juntos, se fazem

45 Evaristo, Ponciá Vicêncio, p. 39.

46 Evaristo, Ponciá Vicêncio, p. 39.

47 Evaristo, Ponciá Vicêncio, p. 42. 
presentes na história. Na narrativa é possível encontrar recordações que despertam os sentidos: a visão, com a descrição dos lares; o tato, com o chão escorregadiço; o olfato, com o aroma do alecrim do colchão de capim; o paladar, com os tachos de saborosos doces de frutas nativas com que as crianças se lambuzavam, segundo nos expõe o trecho a seguir:

As casas das terras dos negros, para o olhar estrangeiro, eram aparentemente iguais. Chão batido, liso, escorregadio, paredes de pau-a-pique e cobertura de capim. As camas dos adultos e das crianças eram jiraus que os homens e mesmo as mulheres armavam com galhos de árvores amarrados com cipós. O colchão de capim era, às vezes, cheiroso, dado ao alecrim que se misturava ali dentro na hora de sua feitura. Os grandes vasilhames de barro ou de ferro e os tachos onde as mulheres faziam doces permitiam imaginar farturas. As crianças gostavam de raspar os tachos se lambuzando com os doces de mamão, cidra, banana, goiaba, leite, abóbora e o melado de rapadura. ${ }^{48}$

O fragmento nos apresenta um cenário de pobreza, entrecortado, entretanto, por fragrâncias, paladares e vida em família, onde adultos, crianças, mulheres, homens, mães e filhos expõem o cotidiano de comunidades povoadas por negros africanos.

Percebemos impressões e vivências da protagonista, da infância à fase adulta. É nítida a biografia de uma mulher negra que vive um processo de diáspora, na intenção de resgatar sua identidade. Desse modo, trabalha como empregada doméstica na cidade, apaixona-se, casa-se, gera alguns filhos e se enxerga vazia, na ânsia de um resgate de si mesma.

Em diversas declarações, ${ }^{49}$ a autora cita vivências, episódios da infância e adolescência que tiveram influência na evolução de seus textos, revelando que sua escrita se inspira e é comprometida com sua existên-

48 Evaristo, Ponciá Vicêncio, p. 59.

49 "Conceição Evaristo: 'Não nasci rodeada de livros, mas de palavras, através da literatura oral': um dos principais destaques da Flip, a escritora Conceição Evaristo conversou com o EL PAÍS", El País, Madri, 30 jul. 2017, <https://bit.ly/2zjn9Vi>, acessado em 14/10/2019; "Depoimento da escritora Conceição Evaristo", <https://youtu.be/heHftI429U4>, acessado em 14/10/2019; "Espaço Público destaca a vida, luta e perseverança da escritora Conceição Evaristo", <https://bit.ly/33zOCAd>, acessado em 14/10/2019. 
cia. Evaristo assevera, em distintas argumentações, que contar histórias continuamente foi uma tradição das mulheres de sua família, dando ênfase à tia Filomena e à mãe como mantenedoras dessa prática. Transmitir de histórias através da oralidade é um intenso traço da tradição cultural africana, que se conservou em nossa cultura brasileira, principalmente nos grupos religiosos afro-brasileiros. A liderança feminina nas famílias e em outras esferas sociais foi uma herança que os grupos afrodescendentes no Brasil conseguiram cultivar na diáspora.

$\mathrm{Na}$ leitura proposta sobre o texto de Evaristo, é importante, sobretudo, refletirmos sobre o processo identitário, partindo de fragmentos que destacam a figura do avô, inteiramente ligada aos conflitos identitários de Ponciá. Assim, a narrativa apresenta em sua estrutura o fluxo de idas e vindas no plano ficcional, representando a diáspora da personagem.

Ademais, o barro é um componente muito presente no texto, referindo-se à arte milenar da modelagem, cultura vinda da África com a diáspora, desempenhada especialmente pelas mulheres, tanto na venda como na fabricação de utensílios domésticos. No entanto, apesar de Ponciá modelar o barro, ser artesã como sua mãe, ela não consegue sobreviver de sua arte.

Não conseguindo reencontrar seu irmão e sua mãe, a personagem continua uma busca por si e, assim, decide ir à procura dos demais parentes na comunidade em que morava, pois:

Todos eram parentes por ali. Desde que os negros haviam ganho aquelas terras, ninguém tinha chegado e eles se casavam entre si. Eram parentes, talvez, desde sempre, de lá de onde tinham saído. Ela decidiu, então, que ia rever os outros, aqueles que também eram os seus. ${ }^{50}$

Ponciá sente o anseio de esculpir o presente, o futuro e o passado. Através do barro rememora a ideia de remodelar a si mesma após uma desconstrução causada pela sociedade e recriar um novo "eu", afirmando e resgatando a identidade extinta pelos processos sociais de segregação.

A busca identitária de Ponciá simboliza a ação de preservar a memória coletiva e individual do lugar de origem, que exerce a função de 
retenção, uma ancoragem de suas ascendências do lar onde nasceu, já que os sujeitos da diáspora vivem seu movimento entre fronteiras, modificando e sendo modificados por meio das práticas culturais e religiosas nas afinidades estabelecidas entre distintos povos no decorrer de suas experiências.

No enredo, há uma denúncia acerca da condição escravizada a que eram subordinados crianças e adultos negros, padecendo sob o poder do imperialismo selvagem dos brancos poderosos: "sob o jugo de um poder que, como Deus, se fazia eterno". ${ }^{11}$ Ponciá relembra sua história e, sobretudo, de outros povos da diáspora africana, que foram trazidos às Américas, espalhados pelo país, especialmente na zona rural, para trabalhar nas plantações. A experiência diaspórica que vários povos têm vivenciado no decorrer do tempo pode ocasionar discussões sobre suas identidades. Dessa forma, a personagem persiste em conservar viva sua memória, que opera como moderador de uma vida carregada de ausências, solidão e perdas. Por meio dos deslocamentos, Ponciá sustenta sua forte ligação com suas raízes, embora não queira para si o destino atribuído aos seus ancestrais.

A ação de rememorar representa um componente que reconstrói posições de um passado remoto, como se aspirasse torná-lo presente, para purificá-lo e, destarte, tentar viver uma história distinta de seus ancestrais. No entanto, Ponciá vai compreendendo paulatinamente que viver na cidade grande não é tão diferente de viver no espaço rural. A labuta era penosa e o estado de pobreza perdurava, alterava o ambiente geográfico, porém não modificava seu "ambiente" social, seus problemas, suas amarguras. Assim, por não ter ânimo para enfrentar tudo, refugiava-se em si mesma, ocultando-se no vazio das ausências. Ponciá Vicêncio sentiu o vazio, e quando retornou a si, ficou tonta.

Tentou relembrar os fatos e não sabia como tudo se dera. Sabia apenas que de uma hora para outra, era como se um buraco abrisse em si própria, formando uma grande fenda dentro e fora dela, um vácuo com o qual ela se confundia. Mas continuava, entretanto, consciente de tudo ao seu redor. [...] No princípio, quando o vazio ameaçava encher a sua pessoa, ela ficava possuída pelo medo. ${ }^{52}$

51 Evaristo, Ponciá Vicêncio, p. 48.

52 Evaristo, Ponciá Vicêncio, p. 44. 
Ponciá era consciente de sua condição, inclusive de que o distanciamento de tudo era sua fuga, seu refúgio. Todavia, eram nesses estados de vazio que ela relembrava sua experiência de tempos passados. Arriscamos afirmar que é através das passagens de memória que o leitor testemunha a história real, que não é somente da protagonista, mas do povo proveniente da África.

A voz narrativa informa sobre a ação oculta do coronelismo, como os "escravos libertos" eram enganados e explorados pelos brancos, mesmo tendo sido "alforriados" pelas leis dos homens:

quando os negros ganharam aquelas terras, pensaram que estivessem ganhando a verdadeira alforria. Engano. Em muito pouca coisa a situação de antes diferia do momento. As terras tinham sido oferta dos antigos donos, que alegavam ser presente de libertação. E, como tal, podiam ficar por ali, levantar moradias e plantar seus sustentos. Uma condição havia, entretanto, a de que continuassem todos a trabalhar nas terras do Coronel Vicêncio. ${ }^{53}$

Segundo Ribeiro, no Brasil, logo após a Lei do Ventre Livre (1871), alguns senhores de escravos ordenavam que os filhos de suas criadas fossem abandonados nas estradas. ${ }^{54}$ Em Ponciá Vicêncio, um acontecimento corriqueiro no período é rememorado na passagem da venda dos filhos de Vô Vicêncio pelo Coronel Vicêncio, mesmo após a promulgação da Lei do Ventre Livre. Vô Vicêncio, apesar de liberto, permanece nas terras onde fora escravizado em troca da promessa de direito a um pedaço de terra, a qual jamais foi cumprida. Exaurido e oprimido durante anos de violência, não detém mais a força física para reiniciar e não alimenta qualquer ambição.

Ademais, a desordem do espaço em que vive no plano físico da narrativa é alterada pela organização de seu lar, que ficou no âmago da vida rural, assim como no íntimo de sua memória. As imagens que as memórias de Ponciá trazem auxiliam o leitor a se familiarizar com os processos de diáspora africana que atravessam a história e a captar a "de-

53 Evaristo, Ponciá Vicêncio, p. 47.

54 Darcy Ribeiro, O povo brasileiro: a formação e o sentido do Brasil, São Paulo: Companhia das Letras, 2006. 
sordem" que eles provocaram, ao massacrar os negros escravizados que vieram da África, isolando-os em várias partes do continente americano.

Em Ponciá Vicêncio (2003), o tempo da narração é relacionado ao da libertação dos escravos, período este de transição. O excerto a seguir recupera esse período:

O coração de muitos se regozijava, iam ser livres, ter moradia fora da fazenda, ter as suas terras e os seus plantios. Para alguns, Coronel Vicêncio parecia um pai, um senhor Deus. O tempo passava e ali estavam os antigos escravos, agora libertos pela "Lei áurea", os seus filhos nascidos do "Ventre Livre" e os seus netos, que nunca seriam escravos. Sonhando todos sob os efeitos de uma liberdade assinada por uma princesa, fada-madrinha, que do antigo chicote fez uma varinha de condão. ${ }^{55}$

Como vimos, em virtude da Lei Áurea, os negros estavam libertos; contudo, aprisionados financeiramente à autoridade escravocrata do Coronel Vicêncio, que mantinha o sistema de escravidão em suas terras. O passado dos ancestrais conduziu, de certo modo, o futuro de Ponciá, que desde criança crescera na penúria e sem educação sistemática, entretanto consciente de que os "negros eram donos da miséria, da fome, do sofrimento, da revolta suicida". ${ }^{56}$

Assim como os demais negros, Vô Vicêncio possuía família, filhos e mulher, que, mesmo nascidos do "Ventre Livre", foram afastados dos seus familiares e vendidos. Perante essa realidade, em que as leis não favoreciam os negros, Vô Vicêncio enlouquece e num ato de desespero assassina a esposa e tenta acabar com a própria vida, não tendo êxito; todavia, resta-lhe a mão decepada a recordá-lo de seu gesto de agressão contra si e obstinação, à medida que se tornara testemunha do desgosto, dos martírios do seu povo, em meio a prantos e risos, até o derradeiro suspiro. A representação de Vô Vicêncio é marcante no romance, e está inteiramente entrelaçada aos conflitos identitários de Ponciá. Assim, para a personagem:

56 Evaristo, Ponciá Vicêncio, p. 82. 
uma imagem se presentificava pela força mesma do peso de seu vestígio: Vô Vicêncio. [...] a estatueta do homem-barro enviesada olhava meio para fora, meio para dentro, também chorando, rindo e assistindo a tudo. ${ }^{57}$

O romance se caracteriza como uma narrativa que apresenta em sua estrutura o fluxo de idas e vindas espaço-temporais no plano ficcional, representando esses deslocamentos e a própria diáspora. A personagem imerge em atitudes de dispersão, isto é, foge para inúmeras partes de um passado longínquo, à procura de restabelecer seu trajeto entrecortado de histórias e vivências de uma vida sofrida: "às vezes, era um recordar feito de tão dolorosas, de tão amargas lembranças que lágrimas corriam sobre o seu rosto"; 58 "outras vezes eram tão doces, tão amenas as recordações que, de seus lábios surgiam sorrisos e risos". ${ }^{59}$

A metaforização utilizada por Evaristo reconstrói a história de modo crítico, ao abordar a temática da diáspora africana, que ainda deixa marcas nos negros no Brasil. Desse modo, formam uma abertura para a imersão de uma narrativa que funciona como reflexo para um mundo que ainda ignora as imagens originárias das reminiscências diaspóricas afro-brasileiras. E, decerto, a migração da personagem-título do interior para a cidade grande representa um subterfúgio da realidade que apenas ratifica a angústia, a dor e a amargura que a circunda.

Conceição Evaristo se afirma como escritora afro-brasileira, ficcionaliza, recorda, inventa e recria, usando como base sua vivência, motivação de escrita que diverge de outros escritores brasileiros, embora seja notório que cada autor traga a sua experiência nas entrelinhas de seu texto. A afirmativa de Evaristo está relacionada a uma ancestralidade, escrita marcada pela condição de mulher negra na sociedade brasileira, descendente de povos africanos, pessoa diaspórica. Essa “afro-brasilidade" possui uma conotação política e ideológica que não pode deixar de ser afirmada.

57 Evaristo, Ponciá Vicêncio, p. 132.

58 Evaristo, Ponciá Vicêncio, p. 93.

59 Evaristo, Ponciá Vicêncio., pp. 93-94. 
Ademais, o texto de Evaristo é marcado pela herança de oralidade que ela carrega, na qual se envolvem e se confundem, em sua escrita, ficção e realidade. São escrituras dolorosas, de memórias de escravidão, de angústias, uma memória ainda "recalcada" e, principalmente, reivindicatória. Evaristo cresceu ouvindo histórias sobre escravidão e intenciona ressignificar a posição dos negros na sociedade brasileira através da revisitação a um passado que permanece "vivo" e presente, na oralidade. Ainda que as primeiras publicações da autora tenham permanecido no círculo do movimento social negro e o principal grupo que legitimasse seu texto fossem sobretudo as mulheres, círculo a que o texto chegava com mais veemência, podemos afirmar que atualmente ela é detentora de um público diverso.

A narrativa Ponciá Vicêncio se constitui através das memórias da protagonista que, do início ao fim, desordena e ordena a narrativa. As lembranças se constroem pelos espaços e imagens, sejam engendradas pela figura moldada em barro de Vô Vicêncio, sejam pelo regresso a locais de feição afetiva para Ponciá.

Posto isto, o fluxo de idas e vindas, no plano ficcional, representa a diáspora da protagonista. Ponciá sente o anseio de esculpir o presente, o futuro e o passado; através do barro rememora a ideia de remodelar a si mesma, após a desconstrução causada pela sociedade, e recriar um novo "eu", afirmando e resgatando a identidade extinta pelos processos sociais de segregação.

Recebido em 24/6/2017 e aprovado em 6/9/2018 


\section{Resumo}

Imersa na vivência dos negros, a literatura afro-brasileira descreve peregrinações, desencantos, sonhos, deslocamentos, trânsitos, encruzilhadas, errâncias e exílios; denuncia a exclusão do afrodescendente; evidencia a relação subalterna do negro em relação ao branco; e expõe tradições africanas emudecidas em nossa cultura. Nesse contexto, acreditamos que a literatura afro-brasileira não é uma concepção desenvolvida isolada do contexto da literatura denominada canônica, contudo requer outra problematização e necessita ser compreendida como um sistema heterogêneo, de movimentos de rupturas, ressignificações e afirmações. Desse modo, os escritores afrodescendentes intencionam, em suas produções, retomar temáticas relacionadas às suas ascendências e vivências, marcadas pela amargura de um ambiente que aparenta não lhes pertencer. Conceição Evaristo, através de Ponciá, consegue dar fala aos derrotados, que descobrem na literatura uma das escassas aberturas para a construção de uma nova realidade. Por fim, a autora é representante de uma escrita que não se limitada a lamentos, mas traz aflições, perturbações sobre questões referentes à identidade negra, escravidão, racismo, pertencimento étnico-racial autoral e ficcional, afetos, ancestralidade, errância, diáspora, corpo negro, religiosidade, branquitude, negritude e memória, uma literatura empenhada com as origens e os valores culturais afro-brasileiros e/ou africanos.

Palavras-chave: literatura afro-brasileira - Conceição Evaristo - Ponciá Vicêncio.

\section{Resumen}

Desde la vivencia de los negros, la literatura afrobrasileña describe peregrinaciones, desencantos, sueños, desplazamientos, tránsitos, encrucijadas, equivocaciones, exilios, denuncia la exclusión del afrodescendiente, evidencia la relación subalterna del negro en relación al blanco y expone tradiciones africanas sin voz en nuestra cultura. En este contexto, creemos que la literatura afrobrasileña no es una concepción desarrollada aislada del contexto de la literatura denominada canónica, sino requiere otra problematización, necesita ser comprendida como un sistema heterogéneo, de movimientos de rupturas, resignificaciones y afirmaciones. De este modo, los escritores afrodescendientes en sus producciones proponen retomar temáticas relacionadas a sus ascendencias y vivencias, marcadas por la amargura de un ambiente que aparenta no pertenecerles. Conceição Evaristo en Ponciá logra dar voz a los derrotados, que descubren en la literatura una de las escasas aberturas para la construcción de una nueva realidad. Por último, la autora es representante de una escritura no limitada a lamentos, sino a aflicciones, perturbaciones sobre cuestiones en torno a la identidad negra, la esclavitud, el racismo, la pertenencia étnico-racial autoral y ficcional, los afectos, la ancestralidad, la errancia, la diáspora, el cuerpo negro, la religiosidad, la blancura, la negritud y la memoria, una literatura comprometida con los orígenes y los valores culturales afrobrasileños y/o africanos.

Palabras clave: literatura afrobrasileña - Conceição Evaristo - Ponciá Vicêncio. 
102 Afro-Ásia, 59 (2019), 77-101 